\title{
Monitoring the sustainable development goals at a local level: information transparency on public health (SDG 3) in Brazilian municipalities
}

\author{
Monitoramento dos objetivos do desenvolvimento \\ sustentável no nível local: transparência da \\ informação sobre saúde pública (ODS 3) em \\ municipalidades brasileiras
}

Diego Pereira Lindoso ${ }^{a}$

Gabriela Litre ${ }^{b}$

Julia Lopes Ferreirac

Kayton Ávila

\begin{abstract}
${ }^{a}$ PhD. in Sustainable Development, Researcher, Centro de Desenvolvimento Sustentável, Universidade de Brasilia, Brasilia, DF, Brazil E-mail: diegoplindoso@gmail.com
\end{abstract}

${ }^{b} \mathrm{PhD}$. in Sustainable Development, Researcher, Centro de Desenvolvimento Sustentável, Universidade de Brasilia, Brasília, DF, Brazil E-mail: gabrielalitre@yahoo.com

'Master in Sustainable Development, Researcher, Rede CLIMA and INCT-Odisseia, Brasília, DF, Brazil E-mail: lopesjulia@gmail.com

${ }^{d}$ Master in Economics, Director of Instituto de Inteligência Gestão e Sustentabilidade, Brasília, DF, Brazil E-mail: kayton.avila@gmail.com

doi:10.18472/SustDeb.v12n1.2021.36601

\begin{abstract}
In Brazil, the process of localizing the Sustainable Development Goals (SDGs) using public databases faces technical, institutional and political challenges. There are essentially no comprehensive current studies regarding the downscaling of the SDG indicators at the smallest territorial levels (e.g., the municipal level). In the context of unprecedented health emergencies, such as the SARS-CoV-2 pandemic, this paper discusses the capacity of the Brazilian public information system to support the localization of SDG 3 (good health and well-being) indicators at the municipal level. This study evaluates the proposed indicators for SDG 3 and databases that underpin these indicators. The results and discussion cover central data and process deficiencies in the public health information systems that hinder SDG 3 localization efforts, the 2030 Agenda and its goal of universality.
\end{abstract}


Keywords: 2030 Agenda. Sustainable development indicators. SDG 3. Public information transparency. Human-health.

\section{RESUMO}

No contexto brasileiro, o processo de localização dos indicadores globais dos Objetivos de Desenvolvimento Sustentável (ODS) apresenta desafios de natureza técnica, institucional e política. Estudos abrangentes e atualizados sobre o desafio de localização dos indicadores dos ODS nas escalas territoriais mais restritas, como a municipal, ainda são incipientes. Em um contexto de emergência sanitária sem precedentes, como a pandemia originada pelo SARS-CoV-2, o presente trabalho discute a transparência e a capacidade do sistema de informação pública brasileiro, com foco no potencial para o monitoramento dos indicadores nacionais do ODS 3 (saúde e bem-estar) na escala municipal. As bases foram avaliadas segundo série histórica, periodicidade, nível de desagregação territorial, incluindo o potencial de análises de subamostras rurais e urbanas. Os resultados evidenciaram deficiências em dados e processos nos sistemas de informação pública que dificultam a localização do ODS 3 da Agenda 2030 e seu objetivo de universalidade.

Palavras-chave: Agenda 2030. Indicadores de desenvolvimento sustentável. ODS 3. Transparência de informação pública. Saúde humana.

\section{INTRODUCTION}

In September 2015, 193 member states of the United Nations (UN) adopted the 2030 Agenda for Sustainable Development), of which Brazil is a member. The development challenges that Brazil faces involve extreme issues in the global context (PAHO, 2009). There are relatively satisfactory performances in some areas of the 2030 Agenda, such as advances in renewable energy access and reduction in maternal mortality ratio (IBGE, 2021a). On the other hand, some performances vary from deficient to poor in other areas, such as the stagnation in the number of tuberculosis cases or the increasing proportion of obese people among the population (SACHS et al, 2020).

Public information is a precondition and fundamental part of progress monitoring in Sustainable Development Goals (SDGs) implementation (LITRE et al., 2020). The efficiency of the decisions made by public managers towards the goals of the 2030 Agenda, as well as the efficiency of those by the third sector and the private sector, requires a comprehensive, consistent, well-organized and easily accessible information database that favours the public policy integration and coherence. These conditions also facilitate the production of scientific knowledge capable of supporting decision making, especially those decisions that affect public policies (MADURO et al, 2020; SANTOS et al, 2019).

The 17 SDGs include 169 targets and 244 global indicators to monitor the progress of the Agenda, which places high pressure on national information systems. Thus, the implementation of the 2030 Agenda monitoring system depends on cross-cutting articulation within a new global agenda of already existing sectorial information systems. A challenge that arises, however, is to tune these systems so that one can build composite indicators with variables from different bases on appropriate scales and resolutions for periodic monitoring within the 15-year horizon of the Agenda (2015-2030). That said, the available information systems often face financial and technical restrictions, thereby putting in check complete and disaggregated databases at different administrative and spatial levels (MCNEILL, 2019; ROMERO \& CUNHA, 2007).

On a global scale, generating the information needed to locate and monitor the progress of the SDGs comes with a high cost (OECD, 2017). At a national level, the cost of maintaining periodic high-quality databases locally is also substantial. It is comprehensible, especially in a country with continental dimensions such as Brazil, whose territory contains 5,570 municipalities (IBGE, 2021b), many of which have technical and infrastructure deficiencies for adequate monitoring. In the current context of scarce resources and the 
prospect of a global recession resulting from COVID-19, optimizing the use of the databases that are already available becomes vital in the process of locating SDG indicators. In this sense, a realistic mapping of the limitations and challenges of the information already available is essential.

Population's health and well-being are gauges of development inequality and represent a country's internal structural inequalities and weaknesses (UN, 2020). In 2020, the right to access health information gained more support with the emergence of the pandemic produced by SARS-CoV-2, which interrupted ongoing processes and redirected data collection efforts and priorities, thereby bringing more urgency to the availability of access to health information and remote data (UN, 2020). Within the 2030 Agenda, the search for health and well-being in the context of inequities and challenges enters in SDG 3 (health and well-being) and its 13 targets and 28 global indicators (UN, 2015).

Nonetheless, within this context, there are no comprehensive updated studies regarding the challenge of locating SDG indicators in Brazil, especially for the analysis of rural and urban samples. This last aspect is of particular importance in rural municipalities, where asymmetries between the dynamics of the countryside and the city have implications for 2030 Agenda effective implementation.

Thus, the present work analyzes the information databases to implement and monitor SDG 3 indicators at the municipal scale. We briefly describe the institutionalization process of global SDG indicators in the Brazilian context in the first section of the paper. The historical process of building a public information system under the principle of transparency is then presented, with a focus on the health information system. In the second part of the paper, the capacity of the public health information system to support the nationalization and localization processes of the SDG 3 indicators is discussed. The results point to deficiencies in temporality and territorial downscaling for some of the indicators, especially at the municipal level. Additionally, we discuss the implications of deficiencies in data quality for completeness and coverage and to the biases due to the so-called garbage codes of the SDG 3 localizing process. Although the results focus on SDG 3, they also support a more comprehensive understanding of the challenges of localizing the other 16 SDGs.

\section{INSTITUTIONALIZATION OF GLOBAL SDG INDICATORS IN THE BRAZILIAN CONTEXT}

The implementation of the 2030 Agenda depends on a transversal governance model based on an efficient system for monitoring the progress of the SDG targets and indicators. Each country that ratified the Agenda became responsible for internalizing the targets in its political-institutional framework. The need to monitor the progress of the SDGs has put pressure on countries' statistical systems to progress from an exclusively national approach to a more integrated and harmonious global information governance system that transcends borders (REIGNER, 2016).

In the Brazilian case, the advancement of the federal institutionalization of the SDGs was subject to the uncertainties of national politics. From an institutional perspective, in 2016, the National Commission for SDGs (CNODS - Brazilian acronym), an interinstitutional parity advisory committee, was created. CNODS was comprised of 32 representatives covering government and civil society whose objective was to internalize, disseminate and provide transparency to the actions related to the 2030 Agenda. These actions included the formulation of the national indicators and the adaptation of the SDG targets to the Brazilian reality.

The Brazilian Institute of Geography and Statistics (IBGE - Brazilian acronym) and the Institute of Applied Economic Research (IPEA - Brazilian acronym) were the federal bodies identified to provide the technical advice for the Committee. In 2018, the IPEA coordinated the process of adapting the 2030 Agenda global targets, while the IBGE assumed the technical lead in developing the Brazilian SDG indicators (IBGE, 2021a). It is further noted that the IBGE chaired the United Nations Statistics Division in 2016 when the SDG indicators were proposed (UNSTATS, 2019; UNSTATS, 2016; SRI, 2016). 
This fact highlights Brazil's technical capacity and strategic position regarding the methodological and operational definitions of the indicators, which is a position that signals the national technical potential to move quickly in the field.

However, since 2019, when President Jair Bolsonaro took power, the 2030 Agenda institutionalization process has suffered important setbacks. Decree No. 9,759, dated 11 April 2019, extinguished all collegiate bodies of the Federal Public Administration created by decree. At the same time, Decree No. 8,243, dated 23 May 2014, which instituted the National Policy for Social Participation, was revoked. One of the countless collegiate bodies affected by the decree was the CNODS, as was its Thematic Chamber on Partnerships and Means of Implementation (CTPMI - Brazilian Acronym). The management of the 2030 Agenda was then transferred directly to the President Secretary, with impacts that have yet to be assessed. That said, it is possible to identify some decisions that reflect changes in the priority of the governmental agenda. Among them, we highlight the presidential veto to include the pursuit of SDG targets in the Brazilian 2020-23 multiannual plan, which considered the inclusion unconstitutional (BRASIL, 2019). In 2021, the Agenda was resumed with the launch of Federal Government's Sustainable Brazil Agenda, which focused on initiatives at the federal level (SEAS, 2021).

Despite the setbacks, the IBGE has been advancing in the process of nationalizing the SDG indicators. For example, it developed a digital platform (Observatory) that has already produced 84 indicators, all of which are distributed by SDGs and targets and associated with the base of the IBGE Automatic Recovery System (SIDRA - Brazilian acronym) (IBGE, 2021a). The remaining SDG indicators are either still in the development stage of the calculation methodology, do not have data or do not apply to the Brazilian case.

Of special importance for the discussion is the territorial scale operated by the IBGE. The institute has been engaged in the process of nationalizing the indicators; however, for the most part, the territorial downscaling of the indicators already produced is only possible up to the scale of large regions and states. The effort to adapt the SDG indicators to more local subnational levels, such as the municipal level, is still incipient, especially in remote regions of the country where there is a lack of data and technical capacity (LOPES et al., 2020).

\section{TRANSPARENCY OF PUBLIC INFORMATION IN BRAZIL}

The access to transparency and quality of public data are key elements for good information governance to support decision-making and well-founded policies formulation. To guarantee the fundamental right to information, Federal Law No. 12,527, dated 18 November 2011, known as the Access to Information Law (LAI in the Brazilian acronym), was sanctioned (BRAZIL, 2011). The regulation of the law defined procedures, deadlines, responsibilities, and generic rights of access to information that had already been established by the Federal Constitution of 1988. The LAI added to other ways of accessing public information already in operation at the time of its implementation, such as the Fiscal Responsibility Law (Complementary Law 101, dated 4 May 4 2000), the Administrative Process Law (Law No. 9,784, dated 29 January 1999) and the Habeas Data Law (Law No. 9,507, dated 21 November 1997), among others. An important initiative was the 2004 launch of the public transparency portal. It became possible to monitor daily updated information around federal budget execution and obtain data on transferred public resources and their direct applications (i.e. origins, values, and receivers).

Other actions also contributed to increasing the transparency of public data in Brazil. The Federal Executive Branch Open Data Policy, instituted by Decree No. 8,777, dated 11 May 2016, brought a new paradigm of transparency and data disclosure that reinforces the concept that all data should be open, except for those of a justified nature that may violate the privacy of the citizen. Activities of the Comptroller General of the Union (CGU) were aimed at presenting technical data translated into everyday language in a transparent, objective manner and with accessible content for people with disabilities. There is also the electronic government (e-Gov). Based on the development and 
improvement of information technologies and the strengthening of the information transparency policy, the service sought a closer relationship and improved dialogue between the government and civil society when observing guidelines for simplifying language and promoting digital inclusion initiatives (LITRE et al, 2020).

Although there have been tangible advances made in the construction of transparent governance of public information, these advances fail to address the challenges they are proposing. Therefore, Brazil continues to face difficulties that put the three types of information control at risk: i) internal control, which is exercised within the same power, whether in the hierarchical scope or through specialized bodies with no hierarchical relationship, or as the control that the direct administration exercises over the indirect administration of the same power; ii) external control, which is exercised by one power over the administrative acts performed by another power, where such control is impaired at the regional level due to the fragmentation and isolation of the decision-making process and the lack of transparency between powers, either intentionally or due to the lack of effective, comprehensive and systematized communication tools; and iii) popular control, which allows civil society and private actors to control the acts practiced by public administration and is a direct result of the principle of the unavailability of public interest (LITRE et al., 2020). There are still challenges in obtaining resources for the availability of data. Besides, improving the quality of metadata to facilitate its use and for disseminating segregated microdata on the smallest possible scale is still complicated (OLIVEIRA, 2019).

Thus, the legal framework for data access does not automatically translate into the expected transparency, especially at the state and municipal levels. A report by Transparência Brasil (2018) noted that six years after the LAI was enforced, the information was still presented by public agencies, either on the websites or in the responses to requests via LAI, in an obscure and unclear language. In the case of city halls, a paradox was identified: sometimes municipal governments refuse to provide information because they consider the request too generic, and sometimes they argue that the consultations would be too specific. From a negative perspective, a common justification is that the research must state whether it will generate additional work for public employees and if so, by law, requests that require extra analysis or production of statistics can be ignored. According to the report, such a principle has served as an argument for public agencies to refrain from providing vital information for social control.

Regarding information access on public health data, the legal framework began to be established in Law No. 8080, dated 19 September 1990, which provides for the Unified Health System (SUS Brazilian acronym). Article 7 of this law ensures that the people have the assisted right to information regarding their health and "disclosure of information regarding the potential of health services and their use by the user" (BRASIL, 1990). To this end, the Department of Informatics of the Unified Health System (DATASUS - Brazilian acronym) was created in 1991 (Brazil, 1991). Besides, the National Health Information and Informatics Policy (PNIIS - Brazilian acronym) is committed to transparency in access to information, with an emphasis on technology and communication actions, to reduce the technical and infrastructure problems faced in the field of information and health informatics in Brazil (BRASIL, 2016).

The information technology (IT) department of the Unified Health System (DATASUS) provides IT support to various health managers at the federal, state and municipal levels and makes it possible to provide different types of data and information. Currently, the registration of health information in Brazil is conducted through several information systems, among which the following stand out: the Information System for Notifiable Diseases (SINAN - Brazilian acronym) (restricted to a list of communicable diseases that are mandatory to notify), the Mortality Information System (SIM Brazilian acronym), the Live Birth Information System (SINASC - Brazilian acronym), the Hospital Information System (SIH-SUS - Brazilian acronym) and the Outpatient Information System (SIA-SUS Outpatient). The SIH-SUS and the SIA-SUS, which are centred on assistance information, highlight the financial database regarding resources destined to hospitals for SUS and contracted networks, in addition to the payment for services performed by public and contracted outpatient networks linked to the SUS. 


\section{METHODOLOGY}

To conduct a critical analysis of the SDG indicators localization challenge at a municipal level, where the Agenda implementation occurs, the present work uses SDG 3 (good health and well-being) to evaluate Brazilian public databases for public accessibility and monitoring of national SDG 3 indicators. To this end, this study uses as a reference the information provided by the IBGE platform for the SDGs (2021a).

First, the formulation status of the national indicators was identified based on the 28 global indicators presented for SDG 3. The indicators were then classified as either (i) produced, (ii) under construction, or (iii) without data, according to the same classification adopted by the IBGE. The indicators identified as produced were then disaggregated into the variables that make up their calculations. For each variable, the database was characterized according to historical series, periodicity, and level of territorial breakdown, including whether rural and/or urban subsample analyses were allowed. This information brought reflections on the limitations of the scope of databases that support the indicators used for the evaluation of the goals of SDG 3.

\section{RESULTS AND DISCUSSION}

More than five years after the 2030 Agenda was launched (2015), only 84 (34\%) of the 244 global SDGs indicators applicable to Brazil have a methodology already defined by the IBGE for the national level (IBGE, 2021a). It appears that the nationalization process has been relatively slow given the short 15-year horizon for the implementation of the Agenda; part of this slowness is the result of structural aspects of the information systems. Approximately $24 \%$ (59) of the SDG indicators do not have the necessary data to be nationalized. Added to this are the technical complexities (methodological adaptations) and institutional challenges, which demand collaboration and cooperation between institutions and skills from different sectors of the Brazilian information system.

This complexity is deepened when the articulation of the SDG monitoring system occurs in a context in which the socio-environmental agenda - to which the 2030 Agenda is closely linked-loses relevance and institutional priority in Brazilian government planning. For example, the extinction of CNODS by the federal decree mentioned above annulled the interface between the state government and civil society to discuss, articulate and implement the Agenda. Furthermore, it annulled the space for creating mechanisms for localizing the SDGs at smaller territorial scales, a process of relevance for the present discussion.

The results from the SDG 3 case corroborate this general picture. Of the 28 corresponding global indicators, Brazil has already adapted the calculation methodology at the national scale for seven of the indicators (25\%). Another $18(64 \%)$ are under analysis or construction, while three indicators (11\%) do not yet have data available at the national scale (Graph 1).

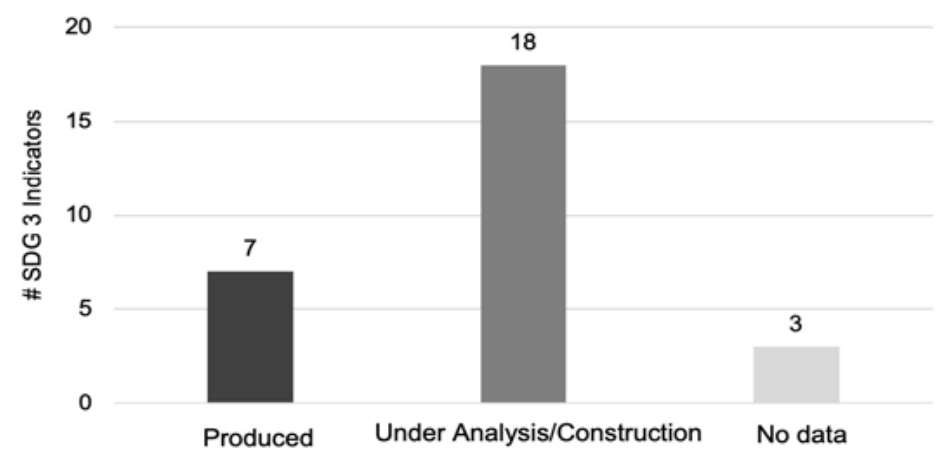

Graph 1 | The number of global indicators (total = 28) of SDG 3 (health and well-being) that have already been produced on a national scale $(n=7)$, have methodology under analysis or construction $(n=18)$ and have no data at the national level $(n=3)$. (Source: authors' own from the IBGE, 2021a) 
SINAN, SIM and SINASC constitute the main information systems of the indicators already produced for SDG 3 (Chart 1). Regarding the use of public information databases for SDG 3 localizing at the municipal scale, out of the seven indicators already produced nationally, six have information that could be disaggregated for all 5,570 municipalities in Brazil (Chart 1). The only limited indicator is 3.8.2, which uses data from the Family Budget Survey (POF - Brazilian acronym), which is a sample survey whose results can be disaggregated only for the urban regions of the metropolitan areas and states' capitals. It is not possible to obtain detailed data for any of the rural areas (Chart 1).

Chart 1 | The seven indicators of SDG 3 (health and well-being) with a methodology already nationalized by the IBGE, based on the data source, available historical series and smallest available territorial scale of the component variables. SIM (Mortality Information System); SINASC (Live Birth Information System); SINAN (National System of Notifiable Diseases); POF (Family Budget Research)

\begin{tabular}{|c|c|c|c|c|c|}
\hline Indicator & Source & $\begin{array}{l}\text { Historical } \\
\text { series }\end{array}$ & $\begin{array}{c}\text { Territorial } \\
\text { breakdown }\end{array}$ & $\begin{array}{c}\text { Rural } \\
\text { area }\end{array}$ & Periodicity \\
\hline \multirow{2}{*}{$\begin{array}{l}\text { 3.1.1. Maternal mortality } \\
\text { ratio }\end{array}$} & SIM & 1996-2019 & \multirow{12}{*}{ Municipal } & \multirow{12}{*}{ No } & \multirow{12}{*}{ Annual } \\
\hline & Sisnac & 1994-2019 & & & \\
\hline \multirow{2}{*}{$\begin{array}{l}\text { 3.2.2. Neonatal mortality } \\
\text { rate }\end{array}$} & SIM & 1996-2019 & & & \\
\hline & Sisnac & $1994-2019$ & & & \\
\hline \multirow{2}{*}{$\begin{array}{l}\text { 3.3.2. Tuberculosis } \\
\text { incidence/100,000 } \\
\text { habitants }\end{array}$} & SINAN & 2001-2019 & & & \\
\hline & IBGE & Since 1975 & & & \\
\hline \multirow{2}{*}{$\begin{array}{l}\text { 3.6.1 Traffic accident } \\
\text { mortality rate }\end{array}$} & SIM & $1996-2019$ & & & \\
\hline & IBGE & Since 1975 & & & \\
\hline \multirow{2}{*}{$\begin{array}{l}\text { 3.9.2. Mortality rate } \\
\text { attributed to unsafe } \\
\text { water sources, unsafe } \\
\text { sanitation and lack of } \\
\text { hygiene }\end{array}$} & SIM & $1996-2018$ & & & \\
\hline & IBGE & Since 1975 & & & \\
\hline \multirow{2}{*}{$\begin{array}{lr}3.9 .3 \text { Mortality rate } \\
\text { attributed } \\
\text { unintentional poisoning }\end{array}$} & SIM & 1996-2019 & & & \\
\hline & IBGE & Since 1975 & & & \\
\hline $\begin{array}{l}\text { 3.8.2 Proportion of } \\
\text { population with large } \\
\text { household } \\
\text { expenditures on health } \\
\text { as a share of total } \\
\text { household } \\
\text { consumption or } \\
\text { income }\end{array}$ & POF & $2008-2009$ & $\begin{array}{l}\text { Metropolitan } \\
\text { regions and } \\
\text { states' } \\
\text { capitals }\end{array}$ & No & Erratic \\
\hline
\end{tabular}

Source: Elaborated by the authors, 2021

The challenge of disaggregating information at the municipal and sub-municipal scales, such as rural and urban areas, faces difficulties when defining a rural-urban typology that can solve the municipal territorial profile. The current definitions are motivated by and follow the logic of tax policies and fiscal objectives. Subsequently, this process imposes the challenge of standardizing such concepts among data collectors from a social perspective. Both countryside and city, as well as rural and urban, are characterized by a wide range of dimensions, such as spatial morphology, occupation and economic vocation, population, population density, mobility and social complexities, homogeneity of the population and way of life (BISPO and MENDES, 2012; KIELING and SILVEIRA, 2015; IBGE, 2017). 
While dichotomous views prioritize the differences between rural and urban environments, they ignore a heterogeneous spectrum of settlements that challenge traditional city and countryside structures (WILLIAMS, 2011). However, the understanding of an imprecise continuum between the highly urban and the extremely rural allows the focus to be on the interconnections and transitions between the countryside and the city, albeit at the risk of ignoring fundamental discontinuities and inequalities (SPOSITO, 2006; BISPO and MENDES, 2012, IBGE, 2017).

In 2017, the IBGE proposed three criteria for the rural and urban space classification that are consistent with the types accepted by the OECD and the European Union: i) the population in areas of dense occupation; ii) the proportion of the population in areas of dense occupation of the total population; and iii) the location (IBGE, 2017). Although it recognizes inherent trade-offs, it also understands these dimensions reflect population behaviours and urban life complexities and dynamism.

With respect specifically to the health sector, this debate is little explored in the literature. Ando et al. (2011) affirm the concept of rural areas is more appropriate when distinguished from the rigid limits of population, geographic and political data, and when related to health indicators, health professionals' practices, health systems characteristics and territory processes involved in the regional dynamics. In this way, they differentiate urban areas from traditionally rural ones and territories within urban centres with exceedingly different dynamics, such as slums, encrusted rural areas and places of difficult access.

In practical terms, such definitions, or the absence of them, are reflected not only in the obstacles associated with locating the SDGs but also in the effective reading of the data, so they can serve as the basis for assertive decision making. As the rural and urban environments determine the allocation of resources, their action plans are quite different as they seek the achievement of SDG 3. In rural and isolated areas, the scope of action for health professional requires expanded interdisciplinary knowledge. It may refer to elements from diagnosis to therapy, intercultural dialogical skills or time and space differences for disease management (ANDO et al, 2011). The scarcity of human and financial resources in these areas demands changes in priorities, such as stabilizing patients for transportation to large centres rather than focusing on immediate treatment, or changes in the role of the health worker with a focus on prevention and awareness on the ground while in the urban centres these tasks are delegated to other professionals. Furthermore, the invisibility of these differences in aggregated indicators does not permit actions that would, in fact, impact, for example, mortality and infection rates or characterize adequate training demands.

Nevertheless, for the territorial dimension, attention is drawn to avoid simplifications in territorially aggregated data analysis. Measures of central tendencies, such as the mean, median and proportion, can mask large internal inequalities in a geographical space, population subgroup or moment. Thus, the importance of observing the internal dispersion of the indicator arises, either by standard deviations, quartiles or maximum and minimum values (among other measures of dispersion), to expose internal heterogeneity. Following PAHO (2018), it is worth mentioning the example of analyzing the infant mortality rate in Brazil in 2013 (15.0 per 1,000 live births). This rate has a limited informative value because this indicator varies from 10.4 (South region) to 19.4 (Northeast region). For example, in the northeast region alone, the rate varies between the states from 14.9 in Pernambuco to 24.7 in Maranhão. Besides, in Maranhão, there is further variability in this indicator (PAHO, 2018). The logic is the same in the disaggregation at the state and municipal levels.

For temporal resolution, in general, the SDG 3 indicators already produced by the IBGE have an annual periodicity and historical series longer than 20 years, which meets the need for periodic and updated information to monitor the progress of the SDG targets until 2030. The only exception, once more, was indicator 3.8.2, which depends on the POF, a survey with irregular and infrequent frequency. The oldest research related to the POF is the National Study of Family Expenditure (ENDEF - Brazilian acronym), which had 1974-75 as a reference year. It was followed by POF 1987-88, POF 1995-1996, POF 2002-03, POF 2008-09, and, more recently, POF 2017-18. However, a preliminary analysis of the latest questionnaires indicates that they did not include the information necessary to calculate indicator 3.8.2 (IBGE, 2021a). 
For this reason, POF 2008-09 is the most recent base available for the development of indicator 3.8.2 of SDG 3, which highlights another limitation of the information system to be considered. The methodological discontinuity between consecutive surveys of the same database can disrupt the historical series and thus create gaps or even interrupt the monitoring of the target until 2030. In this sense, assuming the ten-year interval observed between the last two POFs, the next POF will refer to the year 2027-28. Bearing in mind that there is usually a delay between data collection and dissemination - which can take up to a few years - the results of the next POF may not arrive in time for the monitoring of indicator 3.8.2 within the horizon of 2030 Agenda (2015-2030).

The other SDG 3 indicators either do not have data available or the methodology is still under analysis/ construction (Chart 2). Regarding the latter, as the IBGE had not yet publicly indicated what variables and databases will be used, it was not possible to analyze, in-depth, the limitations that the monitoring effort will face. However, it is possible to make some general considerations based on their formulation. First, it appears that they are indicators that involve epidemiological information, mortality from chronic diseases, coverage of medical care, treatment and health programs, the behaviour of the population and institutional capacity of the health system (Chart 2).

Chart 2 | SDG 3 indicators under analysis/construction or without data, according to their development status1

\begin{tabular}{|c|c|}
\hline SDG 3 indicators not produced yet at national level & Status \\
\hline $\begin{array}{l}\text { 3.1.2. Proportion of births attended by qualified health personnel } \\
\text { 3.2.1. Mortality rate in children under } 5 \text { years }\end{array}$ & \multirow{17}{*}{$\begin{array}{l}\text { Under } \\
\text { analysis/construction }\end{array}$} \\
\hline $\begin{array}{l}\text { 3.3.1. Number of new HIV infections per } 1,000 \text { inhabitants, by sex, age } \\
\text { and specific populations }\end{array}$ & \\
\hline 3.3.3. Malaria incidence rate per 1,000 inhabitants & \\
\hline 3.3.4. Rate of incidence of hepatitis B per 100 thousand inhabitants. & \\
\hline $\begin{array}{l}\text { 3.3.5. Number of people in need of interventions against tropical } \\
\text { diseases }\end{array}$ & \\
\hline $\begin{array}{l}\text { 3.4.1. Mortality rate due to diseases of the circulatory system, } \\
\text { malignant tumors, diabetes mellitus and chronic respiratory diseases }\end{array}$ & \\
\hline 3.4.2. Suicide mortality rate & \\
\hline 3.5.1. Coverage of substance abuse treatment interventions & \\
\hline $\begin{array}{l}\text { 3.5.2. Harmful alcohol consumption, having as reference the national } \\
\text { threshold defined for the consumption of liters of pure alcohol per } \\
\text { capita per year }\end{array}$ & \\
\hline $\begin{array}{l}\text { 3.7.2. Number of live births to teenage mothers (age groups } 10-14 \text { and } \\
\text { 15-19) per } 1,000 \text { women in these age groups }\end{array}$ & \\
\hline 3.8.1. Primary health care coverage & \\
\hline $\begin{array}{l}\text { 3.9.1. Mortality rate due to environmental pollution (external and } \\
\text { domestic) of the air }\end{array}$ & \\
\hline 3.a.1. Prevalence of smokers in the population aged 15 and over & \\
\hline $\begin{array}{l}\text { 3.b.1. Vaccination coverage rate of the population in relation to } \\
\text { vaccines included in the National Vaccination Program }\end{array}$ & \\
\hline $\begin{array}{l}\text { 3.b.2. Official net total development assistance for medium research } \\
\text { and for basic health sectors }\end{array}$ & \\
\hline $\begin{array}{l}\text { 3.b.3. Proportion of establishments that have a basic set of essential } \\
\text { and relevant medicines available and at an affordable cost on a } \\
\text { sustainable basis }\end{array}$ & \\
\hline 3.c.1. Number of health professionals per inhabitant & \\
\hline $\begin{array}{l}\text { 3.7.1. Proportion of women of reproductive age ( } 15 \text { to } 49 \text { years) using } \\
\text { modern family planning methods }\end{array}$ & \multirow{3}{*}{ No data available } \\
\hline $\begin{array}{l}\text { 3.d.1. Capacity for International Health Regulations (IHR) and } \\
\text { preparedness for health emergencies }\end{array}$ & \\
\hline $\begin{array}{l}\text { 3.d.2. Percentage of bloodstream infections due to selected } \\
\text { antimicrobial-resistant organisms }\end{array}$ & \\
\hline
\end{tabular}

1 Terminology for the classification of the status of the indicators determined by the Portal ODS Brasil (IBGE, 2021a): indicators i) produced; ii) under analysis construction; iii) without data; iv) does not apply to Brazil. 
From the description of its statements, it is possible to affirm that, similar to the indicators already produced, the DATASUS information systems will be the main source for calculating the indicators under analysis/construction. As previously discussed, the information made available by the systems has already proven to be a relevant source for the study of morbidities in the country. It is also important to note that they are fully computerized, from the data entry step to the generation of reports, thus allowing easy access to information (BARCELLOS et al, 2008; MENDES et al, 2000; BUSS, 1993).

Although DATASUS manages one of the most well-informed health systems in Latin America, it is noted that the data obtained reflect flaws that are distributed throughout the information production process. These flaws have consequences in terms of the quality of the available data, despite improvements in recent decades (MARQUES et al., 2020; FRANCA et al., 2017; STEVANATO, 2017).

One aspect to consider is the data coverage, which is related to the information system's ability to reach and capture the occurrence of an event in the monitored population (MELLO et al., 2010). The lower the coverage, the greater the proportion of the universe that should be monitored excluded from the systematic registration of the information, thereby creating gaps of information and, consequently, masking reality. Another aspect is completeness, which is a data quality dimension referring to the proportion of fields left blank (information ignored) in the records for a given variable (MARQUES et al, 2020). In this case, the information system reaches the occurrence but records it insufficiently. Different studies have indicated unsatisfactory performance in terms of completeness and coverage of several variables in the SINAN and the SINASC (MARQUES et al, 2020; ROMERO \& CUNHA, 2007). Besides, important territorial and regional asymmetries have been observed. For example, the performance of coverage and completeness tends to be worse in small municipalities in the countryside of Brazil and the north and northeast regions and better in the capitals and the central-south regions (BONILHA et al, 2019; PEDRAZA, 2012; ROMERO \& CUNHA, 2007).

Another major challenge is the use of indicators that require corrections in the distribution of the socalled inaccurate causes of death (garbage codes). These are recorded but cannot be used to inform public policy either because they are related to a vague cause of death, (e.g.: septicemia, whose causes can be multiple) or because they are attributed to a cause that lacks meaning (e.g.: old age). In this regard, the figures seem more encouraging for Brazil. Despite an already demonstrated inverse relationship between socioeconomic development and the incidence of garbage codes, Brazil is considered a country with a good-quality statistical health information system, according to a study by the Global Burden of Diseases (MIKKELSEN et al., 2020). Authors such as Iburg et al. (2015) have explained this phenomenon as the result of the investment made by Brazil to improve causes of mortality monitoring quality and adequately inform decision making in the field of human health (IBURG et al, 2015).

However, at the subnational level, there are significant regional asymmetries in inaccurate death incidence proportionally more relevant in North and Northeast regions (FRANCA et al, 2017). Some of the explanatory factors listed include a lack of methodological clarity in the manual for completion, heterogeneity of professionals who complete the manual, misspellings and transcription mistakes, greater interest in certain variables, and little importance given to other variables during completion (PEDRAZA, 2012).

At the same time, while acknowledging the improvements, there is a latent demand to advance the quality of the health information system by increasing the coverage of the information systems through investments in infrastructure and technology in poor and isolated regions of Braz. For instance, the majority of SUS hospitals do not yet have access to broadband access, which hinders the installation of an electronic medical record system (INCT-ODISSEIA, 2019). Almost half of the Brazilian hospitals are small, with fewer than 50 beds, and have insufficient data management architecture. Some aspects must be improved regarding the correct diagnosis and registration of diseases (INCT-ODISSEIA, 2019). In many cases, the poor training of the employees who create the records results in the inaccurate identification of national epidemiological demands (PEDRAZA, 2012). 
This deficiency in the personnel, in turn, is a reflection of the lack of adequate training, the precariousness and outsourcing of labour, and the conditions that remain despite the efforts to train, qualify and educate SUS workers (MENDES et al, 2000; MACHADO \& CATTAFESTA, 2019). Even those municipalities that acknowledge the potential of data systems to support decision making have difficulties uploading data and using them (MACHADO \& CATTAFESTA, 2019). This reality is different in large urban centres and municipalities with greater socioeconomic power, and thereby the rural-urban contrast and the damaging potential of the transition processes to new technologies and information systems that increase asymmetries are exacerbated (ALLEN, 2017; MACHADO \& CATTAFESTA, 2019).

Regarding the aspects of communication between the information systems, it appears that much of the information lacks reliability and compatibility due to flaws in the standardization of the registry. Besides, the personnel encounters difficulties with the codification of technical language and other obstacles limiting the exploitation of all potentialities and functionalities of DATASUS information systems (PEDRAZA, 2012). Moreover, the health information systems are fragmented, with their management being further fragmented by health institutions that are involved in the production of data. Such institutions include the Ministry of Health's Secretariat for Specialized Health Care (manager of the $\mathrm{SIH} / \mathrm{SUS}$ and the SIA/SUS), the Health Surveillance Secretariat (SVS - Brazilian acronym) (responsible for the SIM, SINASC and SINAN systems), and other institutions not linked to the Ministry of Health, such as the IBGE. A concrete step towards solving this problem is the integration of people's CPF number (Natural Persons Register), which is now mandatory from birth (BARCELLOS \& LOWE, 2014).

The urgent demand for health information generated by the coronavirus crisis was first introduced as a marginal problem when the 2030 Agenda was launched. The pandemic has stressed Brazilian and global health systems beyond their limits to accommodate the impacts. As the demand for information at appropriate scales and resolutions has grown, information limitation has been identified as one of the weaknesses for crisis management. This weakness refers not only to epidemiological data of the disease itself but also to information from the health system at different administrative levels. Thus, data on territorially explicit comorbidities gains critical relevance for information on SUS hospital capacity.

From the analysis of SDG 3, it is clear that the process of localizing the 17 SDGs will require decentralized initiatives from the bottom up that mobilize municipal and nongovernmental databases, on a scale that is even smaller than the municipal databases. Furthermore, these initiatives will require technical training that reflects the local realities to effectively adapt indicators, including other data, that are complementary or alternative to the global and national indicators and are adjusted to specific contexts. This effort is not competing with but is rather complementary to federal and top-down efforts.

Therefore, this effort must communicate with the most comprehensive information systems in the territory, feed both state and regional databases and establish a positive information cycle among the various levels of the state administration. While this principle is anticipated in the proposed implementation of the 2030 Agenda, it is still incipient in Brazil, despite the country's privileged position in the discussion process that gave rise to the global indicators.

As the internalization process is neither automatic nor fluid, the present work emphasizes there are challenges of technical and infrastructural nature. There are also institutional and political setbacks, both circumstantial and historical, that hinder the effective implementation of the 2030 Agenda monitoring system. For optimizing the production and dissemination of pertinent information, among the possible measures, it would be fundamental to adapt the vocabulary of the available data to make information more accessible and standardized, as established by the LAI. It is also recommended that agencies increase archive management and invest, at least, in the digitization of documents. As determined by the Federal Executive Branch Open Data Policy, it is essential to provide society with information in formats that allow for the creation of graphs, tables and other elements that are more suitable for analyses of large amounts of numerical data. 
Finally, we suggest a user-friendly presentation of the data, with an adequate level of aggregation to allow quick and understandable visualization, and in a spatialized way via graphs and maps at the municipal level. To implement these enhancements, important changes in the organizational culture of the government and other bodies at different levels, (i.e. federal, state and municipal), are required to motivate employees to properly record information (especially in the case of public health) and respond more quickly and efficiently to inquiries from nonspecialist citizens. This culture should also provide opportunities for the training and qualifying of the teams in each agency and reward those that demonstrate greater efficiency in complying with the access to public information regulations.

\section{FINAL CONSIDERATIONS}

When analyzing the case of SDG 3 in particular, the present study identified that despite the general slowness of the Brazilian process regarding the nationalization and localizing process of the SDGs, the public health information system reasonably meets the demand for data according to the SDG 3 target indicators. The analysis of the seven already known indicators and the preliminary statement analysis of pending indicators, suggests they use, at different degrees, national databases with adequate spatial disaggregation potentials up to the municipal scale and periodic temporal resolution within the 2030 horizon. Based on the POF, the only exception identified was the indicator 3.8.2, which presents erratic periodicity and methodological discontinuity threatening monitoring capacity for the peri | od covered by the 2030 Agenda (2015-2030).

It should be noted that the relatively satisfactory informational context for monitoring SDG 3 indicators was largely achieved through building a robust health information system that accompanied the implementation of SUS in Brazil. These efforts supported policy health at subnational scales over the past 30 years. As several of the proposed targets for SDG 3 have already been achieved at a national level, one future challenge will be to define goals that equally satisfy all states or meet local specificities since health problems are context-specific in territorially and socially diverse countries, like Brazil.

Conversely, the information system has deficiencies and regional asymmetries concerning the quality of the data produced, especially for coverage, completeness and garbage codes. This implies that the capacity to monitor the implementation of the 2030 Agenda is uneven among Brazilian regions, with the most striking deficiencies being present in precisely the most vulnerable regions and those where the development challenges are the greatest. Similarly, the invisibility of the differences between rural and urban environments within the same territory does not allow the reading of data for assertive decision making for each context. Accordingly, improving the quality and granularity of the data produced by the health information systems is a structuring axis of information governance necessary to monitor the progress of the goals set by the 2030 Agenda. In the wake of this challenge, it is necessary to seek proxies for indicators for which there are no data available at the local levels.

Monitoring the SDG indicators is an organizational driver that can encourage the filling of data gaps and foster the progress of data governance currently engendered by the public information system. In particular, the integration between local and national systems and the improvement of regional asymmetries for data quality are essential so that, as the 2030 Agenda proposes, no one is left behind.

\section{ACKNOWLEDGEMENTS}

We would like to thank the reviewers for their thoughtful comments and efforts towards improving our manuscript. This work was supported by INCT/Odisseia-Observatory of socio-environmental dynamics: sustainability and adaptation to climate, environmental and demographic changes under the National Institutes of Science and Technology Program (Call INCT - MCTI/CNPq/CAPES/FAPs n.16/2014), with financial support from Coordination for the Improvement of Higher Education Personnel (Capes): Grant 23038.000776/2017-54; National Council for Scientific and Technological Development (CNPq): Grant 465483/2014-3; Research Support Foundation of the Federal District,(FAP-DF): Grant 193.001 


\section{REFERENCES}

ANDO, N. et al.; Declaração de Brasília. O conceito de rural e o cuidado à saúde. Revista Brasileira de Medicina de Família e Comunidade, v. 6, n. 19, p. 142-4. Florianópolis, 2011.

ARAUJO, M. et al. The socio-ecological Nexus+ approach used by the Brazilian Research Network on Global Climate Change. Current Opinion in Environmental Sustainability, v. 39, p. 62-70, 2019.

BARCELLOS, C.; LOWE, R. Expansion of the dengue transmission area in Brazil: the role of climate and cities. Tropical Med Int. Healt, v. 19, n. 2, p. 159-68, 2014.

BARCELLOS, C. et al. Georreferenciamento de dados de saúde na escala submunicipal: algumas experiências no Brasil. Epidemiol. Serv. Saúde, v. 17, n. 1, p. 59-70, 2008.

BISPO, C. L. de S.; MENDES, E. de P.P. Rural/urbano e campo/cidade: características e diferenciações em debate. Territórios em disputa: os desafios da Geografia Agrária nas contradições do desenvolvimento brasileiro. XXI ENCONTRO NACIONAL DE GEOGRAFIAAGRÁRIA. UFU, Uberlândia, 2012.

BONILHA, E. A. et al. Coverage, completeness and reliability of the data in the Information System on Live Births in public maternity wards in the municipality in São Paulo, Brazil, 2011. Epidemiol. Serv. Saúde, Brasília, v. 27, n. 1, 2018.

BRASIL. Decreto n 100, de 16 de abril de 1991. Institui a Fundação Nacional de Saúde e dá outras providências, Diário Oficial da União, de 17.04.1991.

BRASIL. Lei n 12.527, de 18 de novembro de 2011. Regula o acesso a informações previsto no inciso XXXIII do art. $5^{\circ}$, no inciso II do $\S 3^{\circ}$ do art. 37 e no $\S 2^{\circ}$ do art. 216 da Constituição Federal, Diário Oficial da União, de 18.11.2011.

BRASIL. Lei $n^{\circ}$ 8.080, de 19 de setembro de 1990. Dispõe sobre as condições para a promoção, proteção e recuperação da saúde, a organização e o funcionamento dos serviços correspondentes e dá outras providências, Diário Oficial da União, de 20.9.1990.

BRASIL. Mensagem no 743, de 27 de dezembro de 2019. Comunica veto ao inciso VII do artigo $3^{\circ}$ do projeto de Lei n²1, de 2019-CN, que "Institui o Plano Plurianual da União para o período de 20202023”, Diário Oficial da União, de 30.12.2019.

BRASIL. Ministério da Saúde. Política Nacional de Informação e Informática em Saúde, BrasíliaDF, 2016

BRASIL. Secretaria Especial de Articulação Social. Secretaria de Governo-Notícias. Agenda Brasil Sustentável reúne estratégias do Governo Federal, 2021. Available at: < https://www.gov.br/secretariadegoverno/pt-br/assuntos/ noticias/ultimas-noticias-1/agenda-brasil-sustentavel-reune-estrategias-do-governo-federal.>.Accessed on: 21 mar. 2021.

BRASIL. Secretaria de Relações Institucionais. Secretaria de Governo da Presidência da República - Notícias, 2016. Available at: <http://www.relacoesinstitucionais.gov.br/noticias/2016/marco/comissao-de-estatistica-aprova230-indicadores-globais-para-monitorar-ods>.Accessed on: 17 maio 2016.

BUSS, P. M. Assistência hospitalar no Brasil (1984-1991): análise preliminar baseada no Sistema de Informação Hospitalar do SUS. Informe Epidemiológico do SUS, v. 2, n. 2, p. 4-42, 1993.

FRANCA, E. et al. Changes in the quality of cause-of-death statistics in Brazil: garbage codes among registered deaths in 1996-2016. Population Health Metrics. 30 September 2020. doi:10.1186/s12963-020-00221-4.

IBURG, K. M. et al. Are cause of death data fit for purpose? Evidence from 20 countries at different levels of socioeconomic development. PLoS ONE, v. 15, n. 8. e0237539, 2020.

INSTITUTO BRASILEIRO DE GEOGRAFIA E ESTATÍSTICA. Classificação e caracterização dos espaços rurais e urbanos no Brasil: uma primeira aproximação. IBGE, Coordenação de Geografia. 84 p. Rio de Janeiro, 2017. 
INSTITUTO BRASILEIRO DE GEOGRAFIA E ESTATÍSTICA. IBGE Cidades: panorama, 2021b. Available at: <https:// cidades.ibge.gov.br/brasil/panorama>.Accessed on: 12 de jan. 2021

INSTITUTO BRASILEIRO DE GEOGRAFIA E ESTATÍSTICA. Relatório dos Indicadores de Desenvolvimento Sustentável, 2021. Available at: <https://odsbrasil.gov.br/relatorio/sintese>.Accessed on: 24 jan. 2021.

INSTITUTO NACIONAL DE CIÊNCIA E TECNOLOGIA. Observatório das Dinâmicas Socioambientais. Panoramas Municipais e Big Data Socioambiental - Plataforma Interativa. Available at: <http://inct-odisseia.i3gs.org/ plataforma-i3data/>.Accessed on: 24 jan. 2021.

KIELING, R. I.; SILVEIRA, R. L. L. O rural, o urbano e o continum urbano-rural no contexto do desenvolvimento regional. Perspectiva, v. 39, n.148, p. 133-143, Erechim, 2015.

LIMA, C. R. A. et al. Revisão das dimensões de qualidade dos dados e métodos aplicados na avaliação dos sistemas de informação em saúde. Caderno de Saúde Pública, v. 25, n. 10, p. 2095-2109, 2009.

LITRE, G. et al. Transparência da informação pública no Brasil: uma análise da acessibilidade de Big Data para o estudo das interfaces entre mudanças climáticas, mudanças produtivas e saúde. RECIIS - Revista Eletrônica de Comunicação, Informação \& Inovação em Saúde, v. 14, p. 112-125, 2020.

LOPES, J. et al. The Contribution of Community-Based Recycling Cooperatives to a Cluster of SDGs in Semi-arid Brazilian Peri-urban Settlements. In: NHAMO, G. (Org.). Sustainable Development Goals Series. Johannesburg: Springer International Publishing, 2020, p. 141-154.

MACHADO, C. D.; CATTAFESTA, M. Benefícios, dificuldades e desafios dos sistemas de informações para a gestão no Sistema Único de Saúde. Rev. Bras. Pesq. Saúde, 2019, p. 124-134.

MADURO ABREU, A. M. et al. The Interfaces Between Health, Climate Change and Land Use in Brazil: a systematic review of international scientific production between 1993 and 2019. Saúde e Sociedade, v. 29, p. 1-16, 2020.

MARQUES, C. A.; SIQUEIRA, M. M.; PORTUGAL, F. B. Avaliação da não completude das notificações compulsórias de dengue registradas por município de pequeno porte no Brasil. Ciênc. \& Saúde Coletiva, Rio de Janeiro, v. 25, n. 3, p. 891-900, mar. 2020.

McNEILL, D. The Contested Discourse of Sustainable Agriculture. Global Policy, v. 10, n. 1, p. 16-23, 2019.

MENDES, A. C. G. et al. Avaliação do sistema de informações hospitalares - SIH/SUS como fonte complementar na vigilância e monitoramento de doenças de notificação compulsória. Informe Epidemiológico do SUS, v. 9, n. 2, p. 67-86, 2000.

MIKKELSEN, L. et al. A global assessment of civil registration and vital statistics systems: monitoring data quality and progress. Lancet, Published on-line v. 6.736, n. 15, p. 60171-4, 2015.

MIKKELSON, L.; RICHARDS, N.; LOPEZ, A. D. Redefining 'garbage codes' for public health policy: report on the expert group meeting, p. 27-28, February 2017. CRVS best-practice and advocacy. Melbourne, Australia: Bloomberg Philanthropies Data for Health Initiative, Civil Registration and Vital Statistics Improvement, University of Melbourne, 2019.

NAÇÕES UNIDAS. Os Objetivos de Desenvolvimento Sustentável no Brasil: saúde e bem-estar, 2020. Available at: <https://brasil.un.org/pt-br/sdgs/3>.Accessed on: 24 jan. 2021.

OECD. Development Co-operation Report 2017: data for development, OECD Publishing, Paris, 2017.

OLIVEIRA, W. Q. Fatores de sucesso na abertura de dados: o caso do Banco Central do Brasil. Brasília: Instituto de Pesquisa Econômica Aplicada - Ipea, 2019.

ORGANIZAÇÃO DAS NAÇÕES UNIDAS. Covid-19 pandemic exposes global 'frailties and inequalities': UN deputy chief, 2020. Available at: <https://news.un.org/en/story/2020/05/1063022>.Accessed on: 29 maio 2020.

ORGANIZAÇÃO PAN-AMERICANA DA SAÚDE. Indicadores de saúde. Elementos conceituais e práticos. 
Washington, D.C., 2018. Available at: <https://iris.paho.org/bitstream/handle/10665.2/49057/9789275720059_ por.pdf?sequence=5>. Accessed on: 24 jan. 2021.

ORGANIZAÇÃO PAN-AMERICANA DA SAÚDE. Mudança climática e saúde: um perfil do Brasil. Brasília: Opas/ Ministério da Saúde, 2009.

PEDRAZA, D. F. Qualidade do Sistema de Informações sobre Nascidos Vivos (Sinasc): análise crítica da literatura. Ciênc. \& Saúde Coletiva, Rio de Janeiro, v. 17, n. 10, p. 2729-2737, Oct. 2012.

REIGNER, M. “Implementing the 'Data Revolution' for the Post-2015 Sustainable Development Goals - Towards a Global Administrative Law of Information.” World Bank Legal Review, n. 7, 2016.

ROCHA, N. M.; ALMEIDA, W. S.; SZWARCWALD, C. L. Avaliação da Qualidade das Informações de Nascimentos no Brasil 2013 à 2015. In: CONGRESSO BRASILEIRO DE SAÚDE COLETIVA, 2018, Rio de Janeiro. Anais eletrônicos [...] Campinas, Galoá, 2018. Available at: <https://proceedings.science/saude-coletiva-2018/papers/avaliacaoda-qualidade-das-informacoes-de-nascimentos-no-brasil-2013-a-2015>.Accessed on: 18 mar. 2021.

ROMERO, D. E.; CUNHA, C. B. Avaliação da qualidade das variáveis epidemiológicas e demográficas do Sistema de Informações sobre Nascidos Vivos, 2002. Cad. de Saúde Pública, Rio de Janeiro, v. 23, n. 3, p. 701-714, Mar. 2007.

SACHS, J. et al. The Sustainable Development Goals and Covid-19. Sustainable Development Report 2020. Cambridge: Cambridge University Press, 2020.

SANTOS, L. et al. Climate change, Productivity Change and Health: complex interactions in the national literature. Ciência \& Saúde Coletiva, 2019.

SPOSITO, M. E. B. A questão cidade-campo: perspectivas a partir da cidade. In: SPOSITO, M. E. B.; WHITACKHER, A. M. (Org.). Cidade e campo: relações e contradições entre urbano e rural. São Paulo: Expressão popular, 2006. p. 111-130.

STEVANATO, J. M.; GAIVA, M. A. M.; SILVA, A. M. Coverage trends of the Information System on Live Births in Mato Grosso, Brazil, 2000 to 2012. Epidemiol. Serv. Saúde, Brasília, v. 26, n. 2, p. 265-274, June 2017.

TRANSPARÊNCIA BRASIL. O que a população quer saber do poder público? Uma análise de respostas a pedidos de acesso à informação de órgãos de todos os poderes e níveis federativos, 2018. Available at: <https://www. transparencia.org.br/downloads/publicacoes/RelatorioLAl_TransparenciaBrasil_2018_vf.pdf $\geq$.Accessed on: 28 maio 2020.

UNSTATS. United Nations Statistical Comission - 47th Session (2016) - Chairs of past sessions, 2016. Available at: <http://unstats.un.org/unsd/statcom/47th-session/>.Accessed on: 24 maio 2016.

UNSTATS. United Nations Department of Economic and Social Affairs - Statistics Division, 2019. Available at: $<$ https://unstats.un.org/sdgs/iaeg-sdgs/>.Accessed on: 14 de fev., 2021

WILLIAMS, R. O campo e a cidade na história e na literatura. Tradução Paulo Henrique Britto. São Paulo: Companhia das Letras, 2011. 439 p. 